\title{
Import and Impacts of the ECHR and the Judgments of the ECtHR in the Russian and German Legal System
}

\author{
Hans-Georg Dederer* \\ University of Passau \\ 39 Innstrasse, Passau, 94032, Germany
}

Received 27.04.2017, received in revised form 29.05.2017, accepted 05.06.2017

In modern constitution-based states, it is, as a rule, the national constitution which determines whether, and to what extent, public international law takes effect in the domestic legal sphere. Accordingly, states may limit or even exclude the validity or applicability of public international law for constitutional reasons. This holds true for the European Convention on Human Rights (ECHR) and the judgements of the European Court of Human Rights (ECtHR) as well. The jurisprudence of both the Russian and the German Constitutional Court provides examples of judicial approaches to limit the validity and applicability of the ECHR or ECtHR judgments within the national legal order.

Keywords: relationship between public international law and domestic law, validity and applicability of ECHR and ECtHR judgments in the domestic sphere, sovereignty, supremacy of the national constitution.

DOI: $10.17516 / 1997-1370-0084$.

Research area: law.

\section{Introduction}

What are the import and impacts of the European Convention on Human Rights (ECHR) in the contracting parties' national legal systems? What are the significance and effects of the judgments of the European Court of Human Rights (ECtHR) in the contracting parties' domestic legal spheres?

These were the topics of the international conference on "Bedeutung und Wirkungen der EMRK und der Urteile des EGMR im russischen und deutschen Rechtssystem" ("Import and impacts of the ECHR and the judgments of the
ECtHR in the Russian and German legal system") organized jointly by the University of Passau (Germany) and the Siberian Federal University in Krasnoyarsk (Russia) on September 23-24, 2016 , on the occasion of the $15^{\text {th }}$ anniversary of the "Deutschsprachiger Studiengang 'Deutsches Recht" ("German-Speaking Programme of Studies in German Law"). These issues are of relevance to all contracting parties to the ECHR. They are of particular importance for both Russia and Germany.

Actually, from a general point of view, the import and impacts of the ECHR and the

(C) Siberian Federal University. All rights reserved

* Corresponding author E-mail address: Hans-Georg.Dederer@Uni-Passau.de 
judgments of the ECtHR in domestic law concern the relationship between public international law and national law. This relationship is not defined by public international law, i.e. public international law itself does not regulate its relationship with national law ${ }^{1}$. E.g., it does not lay down which norm prevails if a norm of public international law conflicts with a norm of national law.

On the contrary, each state decides for itself on the relationship between public international law and its own domestic law, i.e. on the import and impacts of public international law in its internal domestic legal sphere ${ }^{2}$. Against this background, it stands to reason that, in determining the relationship between their own domestic law and public international law, states have an essential interest in asserting their sovereignty.

In modern constitution-based states, sovereignty is expressed, above all, by the supremacy of the national constitution. According to the German Constitutional Court, "sovereignty [is] contained in the last instance in the German constitution"'. Hence, it is for the national constitution to determine whether, and to what extent, public international law takes effect in the domestic legal sphere. The national constitution, thus, forms the basis for, and imposes the limits on, the legal effects of public international law in the internal sphere of the state.

This highlights the core problem: if the states are left to decide the relationship between national law and public international law, they are free to disengage from public international law obligations, albeit only internally with regard to their own domestic legal sphere, by restricting or even excluding the validity or (direct) applicability of public international law for constitutional reasons.

In many, if not most, cases, however, public international law can be practically effective only if it is made binding within the states' legal orders, i.e. if it is implemented in such a way that it becomes internally binding on administrative authorities and courts as well as on individuals ${ }^{4}$. This is particularly true for international human rights law. The protection of the individual by international human rights is void if, and to the extent that, those rights are denied validity and (direct) applicability in the domestic legal sphere.

At the same time, the immense tension between national sovereignty and the state's being bound by public international law is especially reflected in the area of human rights protection. Via international human rights law, public international law takes hold of domestic situations, in particular by governing the internal exercise of governmental authority within the state's territory.

In Europe, this specific tension is further aggravated with a view to the ECHR. Under the ECHR, the individual is empowered to enforce the human rights and fundamental freedoms laid down in the ECHR against any contracting party on the international level by filing a complaint before an international court, namely the ECtHR. In other words, under the regime of the ECHR, purely internal situations are judged finally and bindingly by an international court on the international level on the basis of international law.

Even if public international law may be regarded by some as law which is only poorly enforced, the opposite holds true for the ECHR. There is hardly any other area of public international law in which norms of public international law are enforced more effectively (with the exception, perhaps, of WTO law ${ }^{5}$ and international investment law, e.g. $\left.\mathrm{BITs}^{6}\right)$.

In fact, in many cases, the judgements of the ECtHR deeply interfere with the domestic legal order. Laws need to be amended, court decisions to be set aside, administrative acts 
to be repealed, long-standing legal doctrines to be modified substantially, revisited from scratch or abandoned altogether ${ }^{7}$. Even at the constitutional level, the need for adaptation may arise.

Therefore, it is not surprising at all that quite some of the contracting states to the ECHR try to resist the ECtHR's jurisprudence. National constitutional courts actively participate in such efforts or are exploited for that purpose. They decide, on the basis of the national constitution, whether, and to what extent, ECtHR judgments take effect on the national level. In extreme cases, this may imply that the judgments of the ECtHR have to be considered irrelevant because their observance would be incompatible with the constitution.

In such a case, state sovereignty asserts itself through the national constitution as an unconquerable bastion against the ECHR and the ECtHR. The jurisprudence of both the Russian and the German Constitutional Court provides good examples of judicial approaches to draw 'red lines' serving as a barrier against the validity and applicability of the ECHR or
ECtHR judgments within the respective national legal order.

The first four contributions by Stefanie Schmahl, Valentina Tereshkova, Elena Gritsenko and Julia Haak will be devoted to those constitutional court decisions. The following articles by Marten Breuer, Alexander Zezekalo, Inna Bogdanova, Robert Esser and Tatjana Kondrascheva will illustrate the difficulties of implementing judgments of the ECtHR on the national level in the fields of civil law and criminal law. The final essays by Christian Kalin, Christina Pilina, Clara Herz, Anna Puschkina, Lisa Saponchik and Elena Andreychenko place special emphasis on recent ECtHR judgments or current hotly debated ECHR issues respectively.

All articles brilliantly illuminate the topicality and explosiveness of the themes discussed during the conference. On the one hand, they have recourse to recent, or even most recent, decisions by the ECtHR and the Constitutional Courts of Russia and Germany. On the other hand, the authors are without exception most distinguished experts regarding the subjectmatter of their contributions.

\footnotetext{
Cassese. (2005). International Law, 2nd ed., p. 219.

Cassese. (2005). International Law, 2nd ed., p. 220.

Federal Constitutional Court, Order of the Second Senate of 14 October 2004 - 2 BvR 1481/04, para. 35, BVerfGE 111, 307 (319). Available at: http://www.bundesverfassungsgericht.de/SharedDocs/Entscheidungen/EN/2004/10/ rs20041014_2bvr148104en.html

Cassese. (2005). International Law, 2nd ed., p. 217.

Concerning the WTO dispute settlement system see. (2013). e.g., Van den Bossche/Zdouc, The Law and Policy of the World Trade Organization, $3^{\text {rd }}$ ed,. p. 156 et seq.

6 Concerning international investment arbitration see. (2012). e.g., Dolzer/Schreuer, Principles of International Investment Law, $2^{\text {nd }}$ ed. p. 235 et seq.

Regarding the consequences arising from ECtHR judgments, see, e.g., Federal Constitutional Court, Order of the Second Senate of 14 October 2004 - 2 BvR 1481/04, paras. 40 et seq., 47 et seq., BVerfGE 111, 307 (320 et seq., 323 et seq.). Available at: http://www.bundesverfassungsgericht.de/SharedDocs/Entscheidungen/EN/2004/10/rs20041014_2bvr148104en.html
} 


\title{
Значение и влияние Европейской конвенции \\ по правам человека и решений Европейского суда \\ по правам человека в российской и немецкой \\ правовых системах
}

\author{
Х.-Г. Дедерер \\ Университет Пассау,
}

Германия, 94032, Пассау, Иннштрассе, 39

\begin{abstract}
Как правило, в современных конституционных государствах национальная конституция определяет, действует ли и в какой мере публичное международное право во внутренней правовой сфере. Соответственно, государства могут ограничивать или даже исключать действенность или применимость публичного международного права по конститучионным причинам. Это относится и к Европейской конвенции по правам человека (ЕКПЧ), и к решениям Европейского суда по правам человека (ЕСПЧ). Судебная практика Конституционного суда России и Германии дает примеры судебных подходов к ограничению действенности и применимости решений ЕКСП или ЕСПЧ в рамках национального правопорядка.

Ключевые слова: взаимосвязь между публичным международным правом и внутригосударственным правом, обоснованность и применимость суждений ЕКПЧ и ЕСПЧ в сфере внутреннего права, суверенитет, верховенство национальной конституции.
\end{abstract}

Научная специальность: 12.00.00 - юридические науки. 